\title{
[Academic Translation]
}

\section{Literature and Art Should Not Be the Slaves of the Market (Excerpt from Chapter VI)}

\author{
Written by ZHANG Jiang//Translated by LI Shubin \\ Received: July 11, 2021 \\ Accepted: November 6, 2021 \\ Published: January 31, 2022
}

\begin{abstract}
General Secretary Xi Jinping has delivered important speeches on literature and art since the Eighteenth National Congress of the Communist Party of China. To Achieve Historical Missions of Socialist Literature and Art with Chinese Characteristics for a New Era makes a further study on these important speeches with accurate summary, core vision, and basic thought of literature and art. Based on discussing how to develop the theoretical system, this book explores the interconnection among Xi's speeches on literature and art, revealing the basic rules of our literature and art for a new era and explaining how to seize the opportunity to practice in a new circumstance. This book focuses on the context of Xi's speeches, combining the exploration of theory with the practice of literature and art in China. Under new circumstances, we constantly insist on integrating our practice with the new findings of literature and art to illustrate the value of Xi's thought on literature and art and explore the reality and the connotation of Xi's important speeches on literature and art in a more scientific and objective way. Xi's important speeches on literature and art will provide continuing guidance in the work of Chinese literature and art.
\end{abstract}

Keywords: literature and art; Marxism; socialism; a new era

Notes on the author: Professor ZHANG Jiang holds a doctoral degree of philosophy. He is currently the chief editor of Social Sciences in China.

Notes on the translators: LI Shubin is a MTI student of Jishou University. Her academic interest lies in translation theories and studies.

From the perspective of historical materialism and dialectical materialism, as well as on a high historical and aesthetic level, General Secretary Xi Jinping's series of speeches on literature and art have provided an insightful guidance on the relationship between literature and art and the market in the context of socialism with Chinese characteristics in the new era.

The core of his speeches includes: (1) the development of literature and art should fully respect market rules because literature and art is in the market and they can only survive in the market. (2) Literature and art should adhere to the basic artistic criterion, neither should they lose their way in the market economy nor be a slave of the market and driven by it. (3) the development of literature and art should consider social benefits while yielding decent economic returns, but if economic results hurt social benefits, we should prioritize social benefits. (4) Socialist literature and art are, in essence, the literature and art for the people, and the aesthetic and social edu- 
cation role of literature and art should be brought into play. This requires us to precisely understand and deal with the relationship between literature and art and the market, to adhere to a metaphysical and critical vision of aesthetics and a scientific evaluation scale in practice, and to continuously improve the relevant management and protection mechanisms in the creation of literature and art, so as to create conditions for contemporary Chinese literature and art to advance to the 'summit'.

\section{The Market Creates the Basic Condition for Contemporary Chinese Litera- ture and Art}

General Secretary Xi's speeches on the relation of literature and art and the market are based on a realistic foundation that the market economy has become the dominant mode of China's contemporary economy, 'Many cultural products have to realize their values through the market, but economic benefits should not be completely overlooked'. Strengths constructed markets are now involved in the process of creation, circulation, evaluation, and economic results of literature and art. 'The market, itself, is neither the slave of the market nor the dominator. Writers simply live in an economic environment in which market principles account for a significant proportion. ...The market should not be personified as an opponent who is on opposite sides, but it is a living environment in which writers and artists live. Participating in the market is just like playing a football game - the player is neither the master nor the slave of the market. He is a part of the market, and thus he cannot win the game nor lose it. So does the writer - they live in the market which is the environment they live'. Just as players have to play by the rules, writers should follow the market rules. Regardless of their wishes, they must put their works into the market and painfully compete with other writers to gain reputation and financial gains given by customers. Any literature and art works will not be able to truly acquire the identity of their works, let alone their literary value and social benefits without entering the market. Although the market is invisible, it exerts influences on writers and artists all the time. Such influences are both institutional and conceptual. Specifically speaking, the market has changed the production mode and evaluation criteria of literature and art, and made the division between elegance and vulgarity more refined.

\section{1 The market has changed the production mode of literature and art}

Great changes have taken place in the mode of production shifting from relying on the creation of individual talents to the industrialized collective production which relies on the division of labour with the effects of the market. Although from an ontological point of view, art is a product of collective production. However, the completion of a specific art work depends on the artistic activities of the creator.

Before the market boomed, artists, like craftsmen, could create completed artwork with their own efforts if material costs and commodity circulation were not considered in the process of art creation. Artist's individual talent is a key factor to the successful completion and artistic quality of an art work. Moreover, when an artist creates an art work, they do not have a clear market consciousness because their creation is either a self-entertainment or a production for a specific patron. They always prioritize literature and art's artistic values, not popularity. For writers and artists, rivalries exist mainly in artistic quality rather than the price of their works.

The aestheticians of this period, Kant, Schiller, and future generations of romantics highly admired the con- 
cept of genius on which they think artists are 'geniuses' and they can create art models out of nothing, which symbolizes the human superior spiritual strength. The art production model had undergone a quiet and comprehensive transformation after the rise of capital market - that is, from individual-led production to collective production with a clearer division of labour in the process of production. Marx and Engels had already pointed out that artists are not working in isolation, but working as a part of the division of labour in society and a part of the specific division of labour in art production 'The Requiem in D minor, K. 626 is a requiem mass by Wolfgang Amadeus Mozart. Mozart only composed part of the Requiem in late 1791, and it was unfinished at his death on December 5th in the same year. It was completed in 1972 by Franz Xaver Süssmayr. Raphael died before he could finish his painting...Like any other artists, Raphael was also subject to his previous accomplishments, the social organizations, the division of local labour, the international division of labour which close ties with local conditions. Whether or not people like Raphael could develop his talent depending entirely on the division of labour and the conditions under which people educated by the division of labour produced...Due to the division of labour, artistic geniuses, the artistic talents are purely concentrated in individuals, and thus the artistic genius of the masses is suppressed.'

Driven by the logic of capital, the division oflabour in society is becoming more and more refined, and the division of labour in art field is becoming increasingly refined too. The production of contemporary literature and art consists of a distinct imprint of collective production. Although individual competencies of artists are incredibly important in traditional art, such as literature and painting, while it has been in a secondary position in emerging arts (such as the film and television industry) which relies on the marketing operation. The division of labour of modern art is closely related to markets, of which the division of labour of film, television shows, and popular music has been extended to every chain in production and distribution. There's a shred of significant evidence in the Credits of films and television show.

The reason for this transformation is that the literary and artistic production in the market economy relies heavily on capital and is full of uncertainty. Different from individualized production, industrial production of art consumes not only an enormous of effort and human resources but also requires large capital investments. Even so, as consumer's interest is constantly changing and unpredictable, the art creation in the commercial age must reasonably allocate its resources to avoid market risks. In key sectors of the cultural industry, such as publishing, film, music and visual arts, the vast majority of products end up in the red. Therefore, in order to ensure the success of the investment and financial security, the literary and artistic production in a market-oriented era must make strategic layout according to the market, which may include: overproduction — by overproducing a few successful works to compensate the failure of others; by replicating successful works — by mixing and matching, ' reconstructing' and other means, combing two or multiple successful works into a new piece; by relying on medium hype to promote their products and to create and drive fashion trends.

If cultural products cannot evoke market demands, then investors will make well-timed adjustments to meet the demand and abandon the unpopular art styles and themes. As a result, there will be a variety of conditions in a short term, for example, the proliferation of a specific type of literature and art works; a severe phenomenon of homogenization; the overwhelming and oftern exaggerated advertising campaigns; the overwhelming tendency of the content and form of works to be new and overly strange, and the prevalence of vulgarity, kitsch and vulgarity that can attract the audience's attention; while those works with exploratory nature are difficult to get support be- 
cause of the risk aversion of enterprises, etc. Profitable or not has become an important condition for evaluating the success of literary works.

\section{2 The market has changed the rules of art evaluation}

General Secretary Xi noted at theSpeech at the Symposium on Literature and Art, a good literature and art works must pass test of the audiences, critics, and the market as well. That means the market is one of the indispensable elements of literary criticism. Before the market becomes the main force in regulating literary production, literary criticism is made by comrades in the artistic circles and commenters based on a sharing artistic standard, while economic value is a rather trivial aspect in literary criticism. It's more accurate to say, it is the artistic value of literature and art work that determines its economic value. The elites have a voice and power in artistic criticism and they admire refined culture which requires rich knowledge to interpret and appreciate, in order to exclude the cultural rights of the masses and prevent them from acquiring an artistic identity and participating in art evaluation for a longer period of time.

Under the market economy, however, capital element has become the major adjusting factorof literature and art production and consumption, which means a reproduction of capital is unable to obtain without mass participation. As the literacy rate and purchasing power of the public increase, ordinary people have more say in art evaluation, and their aesthetic taste has gradually influenced the overall cultural form. The changes in reading and evaluation subject have already transformed the ecological system of literature and art. Whether literature and art works can grow in popularity not only determines its financial benefits but also affects its social appraisal.

Although under the conditions of market economy, the economic value of literature and art works base on its artistic value. However, paradoxical phenomenon often occurs: The literature and art work with high artistic value may be difficult to be acknowledged by the masses while the popular one often tends to be vulgar. The economic value has even become the key parameter for people to measure its artistic value. True art is priceless and cannot be measured by money. However, the excessive pursuit of artistic value will make your works too obscure to be popular and lose audience, making it difficult to obtain basic economic benefits.

If artists want to make profits, they must put aside or lower their artistic pursuit and write popular writings, columns, or scripts. Literature and art works play an important role in spreading deep spirit, promoting noblesentiments, denouncing social malaise, and pursuing aesthetic quality before the market becoming dominant force of guiding the production of literature and art work, but now literary works are becoming a consumer good appealing to the special recreation (especially vulgar interests). This is because the production process of literary works is more and more patterned, and increasingly losing its proper ideological power and cultural responsibility, avoiding consumerism and moving from popularity to vulgarity, and shifting from entertainment to pleasure.

\subsection{The market has caused a refinement of the literary and artistic division between elegance and vulgarity}

As mentioned earlier, before the literary market booming, the main standard for literature and art evaluation based on the level of its artistic quality. Accordingly, people distinguished culture into two broad segments: elegant culture and popular culture-popular culture mainly referring to folk culture rather than commercialized popular culture in modern sense. The division between the elegant and the vulgar is gradually differentiated under the role of the market as follows: the culture of true art, which appeals to the cultural elite and art peers. The culture 
of true art is believed to have self-discipline and adheres to the aestheticwith, its own pursuit, innovating art in a new form, challenging the aesthetic taste of public and moral values. The art of orthodoxy, oriented towards upper and middle classes who are well educated with high aesthetic pursuit, adheres to the ideal form of art and morals, and continues to refine them with the hyper spiritual and moral pursuit, tending to be highly recognized and supported by the dominant class. Popular art is oriented towards the masses with the correct educational level and the willingness to buy literary works, and they highly value the entertainment of literature and art works. While these literary works are of a little amount of art value, and many of them highlight economic value than art value. Lowbrow art, oriented towards people who is less educated with poor taste in art, gains better returns by meeting the pleasure of the readers sensual. The artistic style of lowbrow art is vulgar, the quality is poor, and the content is uniform with obvious traces of cliché.

While popular art and lowbrow art share a massive percentage in the art market, there are essential distinctions between them. And because of the above differences in literature and art, we should believe that 'excellent works' what General Secretary Xi said is not unfathomable to satisfy the interests of the elites in art; they should be widely distributed and diverse. Just like what General Secretary Xi said, 'Excellent art works are not confined to one patten, one form or one respect. Writers and artists should not only create works with touching images and superb lyrics that people love, but also reflecting the aspirations of the people.' Literature and art works are all desirable as long as they insist on a certain artistic taste and prioritize people's interests.

\subsection{Literature and art works are special products in the market}

Artistic creation is a unification of material production and mental production. In other words, artistic creation under the condition of capitalism is relative independence and subjected to both the basic law of physical production special law of a certain spiritual production. Karl Marx made a first-ever clarification in Economic and Philosophic Manuscripts of 1844. According to Marx, art is seen as a form and outcome of production in itself. He said art is a special mode of production, which not only falls under its general law but also has its own law, meaning the production of literary works is a unification of the general law of production and the special law on production. 'Religion, family, countries, law, morality, science, art, etc. , are merely particular modes of production and are governed by the general law.' In the preamble to Economic Manuscript in 1857 - 1858, Marx summarized this special mode of production as 'Art Production', and he clarified the fundamental relationship between material production and art production and expounded the imbalance between them with an emphasis on the particularity of art production.

However, it's true that not all art activities and artistic works are art production. Marx illustrated that with the example of Milton, proletariat writers and songstresses who maintain life by singing - Milton sold the rights of Paradise Lost at a price of $£ 5$, and he was not a manual worker. On the contrary, a writer who provides booksellers with a book to sell is regarded as labourer. Milton accomplished Paradise Lost which was inspired by his own nature of writing, although, he sold his art production at the price of $£ 5$ in the end. But a proletariat writer from Leipzig who edited a book named Outlines of Political Economics under the command of booksellers, was a labourer because he sold his labour for wages and the capitalist can increase their revenues with it. A female singer who decided to make a living by singing songs is a non-worker, while a female singer hired by the theater owner was a labourer because the capitalist paid her a certain amount of money for her work. She pro- 
duced capital and her labour increases capital. That is, under conditions of capitalist production, if an artist did not create arts by natural impulse but by producing capital and goods for others, then such labour is deemed as productive labour. Following this logic, the author is a producer with nature of wage labour and creating surplus -value. In this way, under the market circumstances, a literature and art work too is a special kind of commodity. It has aesthetic properties with a utilitarian nature, while it is a commodity that can yield revenues or profits. The former represents its artistic value, whereas the latter represents its practical achievements. 'Practical value is the derivative value or a byproduct of art production, rather than an essential value, nor the fundamental value of literature and art. Moreover, the realization of practical value requires readers to appreciate the aesthetic value of literature and art works; without aesthetic value, practical value is bound to fall short.'

Under the circumstances of market economy, literary and art works should be able to be converted into economic benefits as one of the criteria to measure their success. And if we totally disregard the economic benefits, it is hard for literary and art works to survive under the circumstances of the market economy. Equally, if a literature and art work is driven merely by economic benefits, ignoring aesthetic value, then the work would be inferior in art style and would fail to realize its economic benefits either. From practical point of view, there is no such thing as an aesthetic literary product, nor is there a commercial literary work. Based on the understanding of the duality of art works, we must fully understand and take care of 'the relations of social benefits and economic benefits, the aesthetic and commercial attributes of literature and arts, the aesthetic and utilitarian attributes of literature and art, and the taste in culture and cultural interests of a literary work'. Only in this way can we truly harvest in terms of economic benefits as well as social benefits from literature and art.

Literature and art works have to be put on the market, which is the core proposition for our era. 'To promote the prosperity and development of literature and art, the most fundamental thing is to create and produce excellent works that are worthy of our great nation and great era', as General Secretary Xi Jinping pointed it out in his speech at the Forum on Literature and Art. One of the outstanding characterizations of our era is we are experiencing a process of globalization, the every growing international economy market system, and China's booming and flourishing socialist market economy. Chinese literature and art works will not only be facing domestic competition, but also participating international competition.

The open market is a competitive one, and 'if there were no competition in the market, there could be no vitality in the market". Competition leads to innovation, innovation enhances quality, and quality in turn ensures efficiency. At present, literature and art works are market oriented and their quality can be improved through competition, which is responding to the important proposition of the times. As mentioned above, under the conditions of the market economy, every procedure of the production of literature and art is experiencing new changes. Only by fully recognizing and seizing these changes can writers and artists really take the pulse of the literature and art market and then create works that are highly welcomed in the market and exactly in line with the requirements of this era.

\section{The Development of Literature and Art Is Closely Related to the Market}

'A good literature and art work is ideologically and artistically successful and well received by the market', General secretary Xi Jinping pointed it out in his speech at theForum on Literature and Art. This true insight is 
based on Xi's full understanding of the socialism market development law. Writers and artists must take great efforts to study and analyze the law of literature and art market to better understand the market rule and then seize every opportunity that the market provided. In this way, cultural products of theirs can carry mainstream values and gain more market share. Then our writers and artists can correctly take the market as an effective drive to construct the development of contemporary literature and art and lead the development of the market, rather than blindly placing literature and art on the opposite side of the market and missing good opportunities. If literature and art works were rejected by the market, they might lose their advantage being the mainstream culture and lose the intended audiences. These comments over the issue made by General Secretary Xi Jinping does not come out of thin air, and instead they were developed by the full understanding of thoughts related to the relation of the market and literature and art, which are posed by the writers, artists, and theologians nowadays or in the past, or domestically or overseas. In short, the development of these thoughts referring to market and literature and art have undergone a process of rejection to acceptance and utilization.

\section{1 The market lays a foundation for the development of literature and art works}

Facing the real market, there's going to be a lot of encounters for different authors of various attitudes or opinions. Typically, some of them view the market as a monster that destroys the quality of literature and art works. Quintus HoratiusFlaccus (8 December 65 BC - 27 November 8 BC), the leading Roman lyric poet during the time of Augustus, assessed Roman who were good at calculating and obsessed with economic affairs as if money clouded our eyes and greed corroded our mind, how could we hope that the poetry we created is worth painting with fir tree resin and be preserved in a smooth cypress box?' What he said clarified the connections between art and money, and categorized literature and art works created for pursing profits as inferior ones. William Wordsworth, an English Romantic poet, concerned about the market would make literary and art works to be vulgar, while Mathew Arnold, an English poet and cultural critic, worried about popular culture driven by the market would compromise the unification of beauty and goodness of literature and art works. As for contemporary philosophers, take some intellectuals from Frankfurt School for an example, especially Max Horkheimer and Theodor W. Adorno, drew the fiercest criticism for the role of the market in ruining the quality of literature and art. They believe that under the role of 'cultural industry' with capital logic as its fundamental mode of operation, literature and art products have become shallow and vulgar, repetitive and devoid of individuality under the influence of money. Chinese writers and poets have long believed that literature and art creation for the sake of money endangers their inherent dignity and reputation. Gong Zizhen, a Chinese poet, calligrapher, and intellectual, complained that 'writing for making a living or for personal safety', which can be said as a penetrating criticism on writing just for making a living. The aforementioned statements have been be amplified under the circumstance of ever-increasing capital market, which have become values of tremendous influence on the literature and art world.

However, a review of the developmental history of literature and art in China and the West indicates that literature and art and the market are not mutually detrimental and antagonistic; rather, they are complementary and mutually beneficial. The period when literature and artistic creations are more active and excellent literature and art works sprung up in a large number was also often a period when commodity economic boomed. The aesthetic and commercial aspects of literature and art works cannot be over-emphasized but favored under specific condi- 
tions. Not only will the development of the market not lead to the decline of literature and art, but it will cast a sort of brilliant twilight over the development of literature ana art. Under the mature market, the rules for literature and art will be finalized and to be mature. Above all, it means that the market provides artists with a wider range of intended audiences and a broader source of income, allowing them to acquire independent personalities, which in turn enables them to have more autonomy inther art creations.

In China, as early as the Jin Dynasty (a Chinese dynasty traditionally dated back from 266 to 420 AD), the Song Dynasty (960 - 1279), and even in the Han Dynasty (206 BC - 220 AD), poets and writers would compose and send their writing to someone as a gift to express their gratitude. During the Tang Dynasty $(618-907)$, literatus would write an essay (often to be a formal epitaph), and they tended to receive a generous remuneration for polishing others' manuscripts. In the period of the Nan (Southern) Song Dynasty (1127-1279), the economic prosperity in Suzhou and Hangzhou, which gave the literati a chance to gather in Hangzhou associating with each other and then creating abundant of poetries. In this way, the market has gradually become one of the important mechanisms restricting the development of literature and art beyond the official ideological requirements and the criticisms of literates. During the Ming Dynasty (1368 - 1644) and Qing Dynasty (1644-1912), the commodity economy witnessed a further development and subjects of literary works were diverse, including the poetry and writings preferred by the Chinese literatus, romantic and crime fictions which were popular among common people. With the effect of the market, conflicts between refined and vulgar literature and art have become much more integrated; thus, they eventually formed market-oriented popular literature and art works. The period of the late Qing and the early Republic has witnessed a development of the capital market and the abolition of the imperial examination system, freeing a large number of intellectuals selling calligraphies and paintings to make a living, which led the literature and art market to unparalleled prosperity.

The rapid development of the modern newspaper industry and the establishment of pay system gave rise to one of the first market-oriented 'professionalnovelists'. At that time, newspaper was the main social medium to spread news. To survive in the market, newspapers needed to secure advertising sponsorship, which required certain literary forms published on newspapers. 'In the period of the late Qing, not all literature and art works ( such as poetry and literature) could be paid, except for writing novels due to their popularity or large volume, which could bring good profits to the publishers, Thus, writers could be paid.' Does that mean that all works published in the newspapers are of poor literary qualities? Not exactly. But with the passage of time, many works published at that time, such as The Travels Of Lao Can by Liu E, Bizarre Happenings Eyewitnessed Over Two Decades by Wu Jianren, Officialdom Unmasked by Li Boyuan, The Death of Yuli by Xu Zhenya, and others, have good artistic qualities and have become literary classics, judging by today's artistic standards.

In the modern period, especially around the 1930s, China's national capitalism made great progress and the literary and artistic market became more prosperous, which encouraged the creation of diverse works to meet popular customer demand. Lu Xun who was a Chinese writer, essayist, poet, and literary critic, Guo Moruo who was a Chinese author, poet, historian, archaeologist, and government official, Mao Dun who was a Chinese essayist, journalist, novelist, and playwright, Ba Jin who was a Chinese writer and author, Lao She who was a Chinese novelist and dramatist, and Cao $\mathrm{Yu}$ who was a Chinese playwright, all have a major part in the modern literary market, not to mention the market-oriented 'Mandarin Ducks and Butterflies school' (a popular genre of Chinese fiction in the first half of the 20th century, especially in the 1920s, the genre encompassed 
more than romance stories ) - Zhang Henshui was from such school. Duiring this period, 'elegant literature' advocated by elite literati, as well as more market-oriented popular literature such as official condemnation novels, crimne case novels, romantic fictions or Kongfu novels had significant development. More crucially, Chinese writers had gradually shaken off the attachment of bureaucrat since the Ming and Qing Dynasties, allowing them to detract from the paths to normal life, whether to be an official by passing the imperial examination or to be an assistant to a ranking official or general, and making them economically independent, ideologically free or being unorthodoxy, as well as enabling them not to blindly accept orders of the imperial court or act according to the official ideology. They had been giving up the direction-taking of using literary works to deliver doctrines of the imperial system, whereas they followed the marketing trends appealing to the readers' taste. In this way, they had gained independence in personality and at their works.

After the founding of the People's Republic of China, the marketization of literature and art was interrupted, artists were admitted to the system and were paid by the government as the main financial source. Politics and social benefits became the indispensable factors to evaluate literary works, and even administrative orders and documents were used to guide writers. Although there were some excellent works, the overall decline in literature and art's vitality was apparent. Therefore, in the early stage of reform and opening-up, the first problem of the reforming of literature and art waiting to be solved is fueling literature and art with inner drive, which means we must further liberate thoughts in the field of literature and art and then relive the freedom of creation. "What to write and how to write can only be explored and decided by writers and artists in their own artistic practice. In this regard, interferences are unnecessary', said by Deng Xiaoping in his speech at the Fourth Congress of China Literary and Art Workers.

Solid steps were taken to further liberate thoughts in the field of literature and art and relive the freedom of creation, and the betterment of the socialist market economy structure laid a better foundation for a more prosperity literature and art market and led to a transformation in the literary system. In advancing reform and openingup, deep reform is taken in state authorities and institutions. In this process, some literary and artistic institutions were made to take part in the literature and art market. Thus, a bunch of writers and artists who used to work in the public sector now work as a freelance writers or artists creating fine works to make a living. They must deal with the relationship between personal artistic style and market demand. Even for those who are still working in the public sector are affected. Therefore, the market plays a decisive role in regulating marketing activities once again.

(Editor: Joe Zhang) 